\title{
Analysis of Uneven Regional Development in North-East, Middle-Southeast, and West-South Regions of Aceh Province
}

\author{
Yayuk Eko Wahyuningsih" ${ }^{*}$, Irfan Syah Putra ${ }^{2}$, and Eni Meliana ${ }^{3}$ \\ 1,2,3 Teuku Umar University, Meulaboh, Indonesia
}

\begin{abstract}
Aceh is a province of Indonesia that currently consists of 23 districts/municipalities that are generally divided into three (3) regions, namely, the Northeast (11 districts/municipalities), the Middle-southeast (4 districts) and the Southwest ( 8 districts/municipalities) regions. These regions have different natural, human, social, political, and cultural resources. These differences have caused uneven economic development, which has further caused developmental disparity among the regions.

This study aims to assess the extent of developmental disparity among regions and to analyze the impact of Gross Regional Domestic Product per capita on regional developmental disparity in the three (3) regions of Aceh province in the period of 2000-2014. The data used in this research are secondary data that were obtained from the Central Statistics Agency (BPS), and the Regional Development Planning Board (Badan Perencanaan Daerah/Bappeda) of Aceh Province. To identify the level of inequality, the researcher utilizes Williamson Index; whereas to determine theimpact of Regional GDP per capita on the inequality of regional development, the researcher utilizes a semi logarithmic linear regression model that includes a discussion on the correlationcoefficient $(R)$, determination coefficient ( $R$ Square), and t test using SPSS.

Based on estimation results, the researcher discovers that, for the NorthEast region, the value of correlation coefficient $(R)$ is 0.8032 , the value of determination coefficient is $64.52 \%$, and the equation for $Y$ is $Y=-1.8942+$ 0,1263X;for the Middle-Southeast region, the value ofcorrelation coefficientis0.6760, the value of determination coefficient is $45.70 \%$, and the equation for $Y$ is $Y=0.6441+0,0400 X$, and;for the Southwest region, the value ofcorrelation coefficientis 0.4045 , the value of determination coefficient is $16.36 \%$, and the equation for $Y$ is $Y=-0.4703+0,0318 X$. As for the t test, the researcher discovers that for North-East region the per capita regional GDP wast $\left._{\text {count }}\right\rangle$ $t_{\text {table }}(4.671>1.7823)$; for the Middle-Southeast regional $t_{\text {count }}<t_{\text {table }}(-$ $3.178<1.7823)$, and; for the Southwest region $t_{\text {count }}<t_{\text {table }}(1.532<1.7823)$. These per capita regional GDP values mean that only in the Northeast region does the variable of per capita regional GDP have a real impact on the variables of regional developmental disparity. This is consistent with the fact that the Northeast region is much more advanced and developed than the other two regions.
\end{abstract}

JEL Classification: O10, O11, O15

Keywords: GDP, Index of Williamson and Discrepancy, Per capita GDP, Total of population

\footnotetext{
* Corresponding author. Email address: yayukew@utu.ac.id
} 


\section{INTRODUCTION}

\section{Background}

Economic development is a process of income increase, total income or per capita income, which is followed by an increase in the number of people as well as income equalization for the people of a country. The goal of economic development of a country is to increase the welfare of the people. The welfare can be realized through an increase in the economic growth of the country occurring due to the income equalization of the people of the aforementioned country, obtained through the Gross Regional Domestic Product (GRDP) of a region or the Gross Domestic Product (GDP) of a country.

The GRDP values differ from one region to another because of comparative advantages that are affected by environmental conditions, the mastery of the people in advanced technologies, the mastery of the people in certain skills, central regions of activities, low wages for and plentiful availability of labor, and other factors. Such is the case for Indonesia, composed of 33 provinces, where the regional development condition among provinces is unequal or very different.

Further, the Province of Aceh, a region of Indonesia which at this time (2016) is composed of 23 regencies and cities, possesses differences in natural, human, social, political, and cultural resources among its regencies and cities, and these differences are what have caused economic development to be uneven, creating gaps in development among the regions.

Based on regional classification, this province can be divided into three regions, which are North-East, Middle-Southeast, and West-South. In the 1980s up until the 2000 millennial year, the North-East region represented the region of which its development condition was the best compared to the other regions of the Province of Aceh, because this region is an industrial zone with the establishment of several giant factories in the fields of oil and gas, fertilizer, paper, and other industries. One of them is the ASEAN Aceh Fertilizer (AAF) factory, which is owned by several ASEAN countries. In addition, the region is strategically placed, where the cities and regency capitals are situated along the national road, which allows good access to its neighboring province, North Sumatera.

The Middle-Southeast region represented the region for which the development of physical and non-physical infrastructure lags far behind, compared to North-East region, because this region is composed of forests and plantations, most of which were not very productive. The same is true of the West-South region, which is an agricultural zone, but still at a small scale.

One of the indicators that show the gap in economic development of a region in a certain time period is the constant-price GDP. The GRDP of Aceh from 2009 to 2013 experienced an increase, though this was not significant. In 2009, the constant-price GRDP was Rp. 32,219.09 billion and the constant-price GRDP growth was $-5.51 \%$; up to 2013 the constant-price GRDP was Rp. 38,012.97 billion and its growth was $4.18 \%$.The GRDP data of every regency or city can be seen in Appendix 1.

The increasing number of people will cause the number of laborers to increase. The increasing number of laborers, balanced by a greater number of work openings, will result in more people being able to work. The populations of the regencies and cities can be seen in Appendix 2. One of the ways to increase the welfare of the people is by increasing economic growth. Meanwhile, the increase 
in economic growth is shown by the increase of per capita GRDP and per capita income of the region.

\section{Formulation of the Problem}

The following is the formulation of the problem for this research:

a. How great is the gap of regional development among the North-East, MiddleSoutheast, and West-South regions of the Province of Aceh?

b. What is the influence of the per capita GRDP toward the gaps of the NorthEast, Middle-Southeast, and West-South regions of the Province of Aceh?

\section{Objectives of the Research}

The objectives of this research are, among others:

a. To analyze how great the gap of regional development is among the NorthEast, Middle-Southeast, and West-South regions of the Province of Aceh.

b. To analyze the influence of the per capita GRDP toward the gaps of the NorthEast, Middle-Southeast, and West-South regions of the Province of Aceh.

\section{LITERATURE REVIEW}

\subsection{Economic Development}

According to Sukirno (2006:3), economic development is a series of economic efforts to develop economic activities to increase available infrastructure, create and develop more factories, elevate the level of education, and make more technologies available, and thus the implication of this development are expected to be greater work opportunities, increased income levels, and greater welfare for the people.

Next, economic development is taken to be a process that causes the per capita income of a certain group of people to increase, where the increased income is a reflection of the improvement in economic welfare of the people, yet is also accompanied by the eradication of poverty and management of income gaps (Amalia, 2007:1).

\subsubsection{Regional Economic Development}

Regional economic development is the increase of income of the people as a whole that occurs in a certain region, which is the occurrence of the increase of all added values. The calculation of regional income is initially in the form of applicable prices, but in order to see the development from one time period to the next, the real prices must be stated, which means stating constant prices (Tarigan, 2005: 46).

\subsection{Regional Development Gap}

According to Adisasmita (2005:116),disparities among regions show the existence of a gap or difference in the level of progress or welfare or a difference in the level of progress or welfare of one region with another due to the effects of mobility and accessibility (ease of transport). Mobility represents the level of movement of people and goods from one place (region) to another. A high rate of mobility is shown by the availability of facilities and infrastructure of transportation in a sufficient capacity, which provides transportation services in a smooth (quick) manner.

Gaps have positive and negative effects. The positive effect of gaps is to encourage other underdeveloped regions to be able to compete and boost development to increase prosperity. Meanwhile, the extreme negative effects of gaps are among others economic inefficiency, lowered stability and solidarity, and unfairness based on the size of the gap (Tadaro, 2006: 249). 


\subsubsection{Factors That Affect Regional Development Gaps}

The primary factors that cause or trigger the existence of regional gaps are among others: (Sjafrizal, 2008:117-120)

a. Differences in natural resource content

b. Differences in demographic conditions

c. Lack of smooth mobility of goods and services

d. Concentrated regional economic activities

e. Allocation of interregional development funds

\subsubsection{Management of Regional Development Gaps}

The efforts to overcome the issue of regional development gaps can be performed through the distribution of transportation infrastructure development to make smooth the mobility of goods and interregional production factors, encouragement of spontaneous transmigration and migration to resolve the issues of shortages and excesses of laborers, development growth centers to reduce interregional gaps, and execution of regional autonomy so that regional development activities, including in lagging regions, will and can be encouraged due to authority of the government and people; as such the initiative and aspirations of the people to uncover regional potential can be encouraged, enabling the elevation of the process of regional development (Sjafrizal, 2008. h. 121-124).

\subsection{Williamson Index and Agglomeration}

Sjafrizal (2008:108) stated that the Williamson Index is one of the tools for measuring the size of regional gaps, which was first used by Jeffrey G. Williamson. The calculation of the Williamson Index is based on the GRDP data of each region. The measurement results of the Williamson Index is shown by a value from 0 to 1 , or $0<\mathrm{VW}<1$; as the Williamson Index approaches 0 , the regional development gap becomes smaller, and as the Williamson Index approaches 1, the regional development gap becomes larger.

\subsection{Formulation of the Hypothesis}

The hypothesis is that:

a. It is suspected that the highest gap occurs with the Middle-Southeast region, followed by the West-South and North-East region.

b. It is suspected that the per capita GRDP has a real influence toward regional development gaps.

\section{RESEARCH METHOD}

\subsection{Research Scope}

The scope of this research covered the constant-price Gross Regional Domestic Product (GRDP) of the year 2000, the size of the population, and the per capita GRDP of three regions in the Province of Aceh in the years of 2000-2014 with secondary data from BPS.

\subsection{Data Analysis Model}

The data analysis model used in this research was quantitative analysis using the Williamson Index and semi-logarithm regression processed using the SPSS software.

\subsubsection{Williamson Index}

According to Safrizal (2008:1), in order to provide a better picture of the development of each region based on the equalization of the development, the 
index of interregional gaps as initially used by Jeffrey G. Williamson can be used, as formulated below:

$$
\mathrm{VW}=\frac{\sqrt{\sum_{k=0}^{n}\left(Y_{i}-Y\right)^{2}\left(f_{i} / n\right)}}{Y} 0<\mathrm{VW}<1
$$

Where:

$\mathrm{Y}_{\mathrm{i}} \quad=$ Per capita GRDP of region $\mathrm{i}$ (regional)

$\mathrm{Y}=$ Average per capita GRDP of all regions (Aceh)

$\mathrm{f}_{\mathrm{i}} \quad=$ Population size of region $\mathrm{i}$ (regional)

$\mathrm{n} \quad=$ Population size of all regions (Aceh)

\subsubsection{Semi-Logarithm Analysis}

According to Sarwoko (2005: 93), to obtain more significant results and ease the calculation process, the linear regression equation is formulated in the semi-logarithm form as below:

Where:

$$
y=b_{0}+b_{1} \operatorname{Ln} x+e
$$

$\mathrm{y}=$ Gap (dependent variable) measured on a scale of 0-1

$\mathrm{x}=$ Per capita GRDP (independent variable) measured in rupiahs

$\mathrm{b}_{0}=$ Intercept (constant)

$\mathrm{b}_{1}=$ Regression coefficient of factor $\mathrm{x}$

$\mathrm{e}=$ Error term

\subsection{Hypothesis Testing}

Based on the testing of the hypothesis:

a. If the Williamson index approaches 0 then the regional development gap is small and if the Williamson index approaches 1 then the regional development gap is large.

b. A greater agglomeration on value of a certain region indicates a higher concentration of economic activities in that region.

c. If $\mathrm{H}_{0}: \beta_{1}=\beta_{2}=0$, it is suspected that the per capita Gross Regional Domestic Product being researched does not have a significant influence on the regional development gaps among regions in the Province of Aceh. If $\mathrm{H}_{1}: \beta_{1}=\beta_{2} \neq 0$, it is suspected that the per capita Gross Regional Domestic Product being researched does have a significant influence on the regional development gaps among regions in the Province of Aceh.

The t-test criteria for the hypothesis established in the research are:

a. If $t_{\text {count }}>t_{\text {table }}$, then $\mathrm{H}_{0}$ is rejected and $\mathrm{H}_{1}$ is accepted, which means that there is partially a significant influence between the per capita Gross Regional Domestic Product and the interregional development gaps among the regions in the Province of Aceh.

b. If $\mathrm{t}_{\text {count }}<\mathrm{t}_{\text {table }}$, then $\mathrm{H}_{0}$ is accepted and $\mathrm{H}_{1}$ is rejected, which means that there is partially not a significant influence between the per capita Gross Regional Domestic Product and the interregional development gaps among the regions in the Province of Aceh. 


\section{RESEARCH And RESULTS}

\subsection{GRDP of the Province of Aceh}

The Gross Regional Domestic Product is a picture of the economic development of a region that is resulted from the production values of goods and resources produced by a certain region in a certain year. The following is the constant-price Gross Regional Domestic Product of the Province of Aceh in the years 2000-2013.

Table 1 Constant-Price GRDP of the Province of Aceh, 2000-2013

\begin{tabular}{ccc}
\hline No & Year & $\begin{array}{c}\text { Constant-Price Gross Regional Domestic Product in } 2000 \\
\text { (Million Rupiah) }\end{array}$ \\
\hline 1. & 2000 & $17.397 .989,02$ \\
2. & 2001 & $17.766 .923,24$ \\
3. & 2002 & $18.221 .417,04$ \\
4. & 2003 & $18.843 .073,79$ \\
5. & 2004 & $19.803 .550,26$ \\
6. & 2005 & $19.991 .350,51$ \\
7. & 2006 & $22.760 .622,49$ \\
8. & 2007 & $24.542 .943,10$ \\
9. & 2008 & $25.682 .967,11$ \\
10. & 2009 & $26.847 .009,10$ \\
11. & 2010 & $28.118 .582,51$ \\
12. & 2011 & $29.459 .224,26$ \\
13. & 2012 & $30.904 .408,44$ \\
14. & 2013 & $32.349 .707,68$ \\
\hline
\end{tabular}

Source: The Central Agency for Statistics of the Province of Aceh (data processed in November 2014)

Table1 shows the development of the constant-price GRDP of the Province of Aceh, where in the period of years of 2000-2013, the GRDP continued to increase. The highest GRDP occurred in 2013 and the lowest GRDP occurred in 2000; this condition has a positive impact on the economy of the Province of Aceh. 


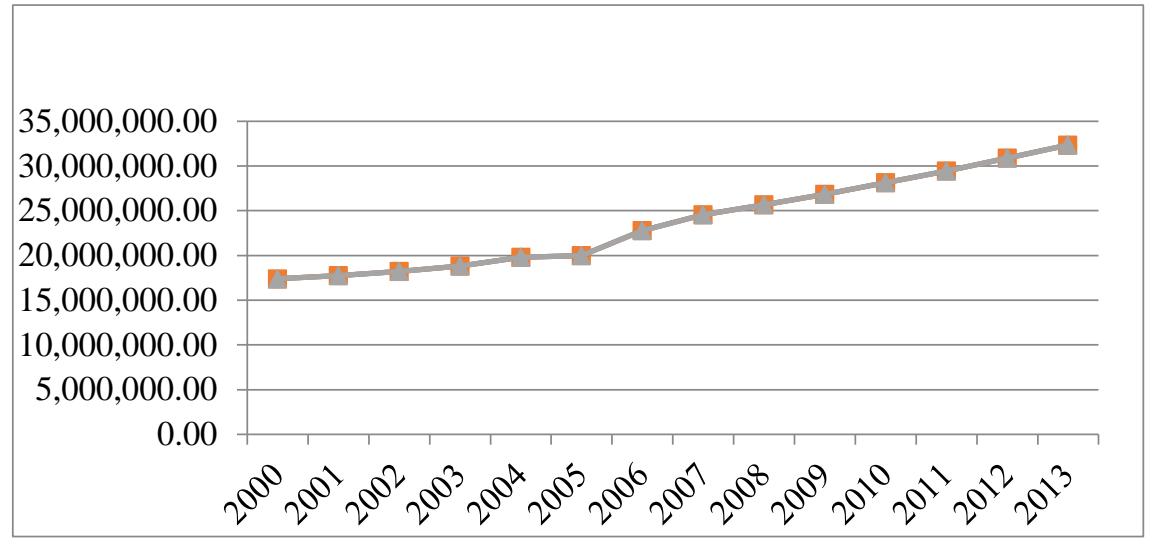

Figure 1 Constant-Price GRDP of the Province of Aceh of Years 2000-2013

Source: The Central Agency for Statistics of the Province of Aceh

Figure 1 shows the development of the constant-price GRDP of the Province of Aceh in the period of years of 2000-2013, with the highest GRDP having occurred in 2013 and the lowest GRDP having occurred in 2000.

\subsection{GRDP Per Capita of the Province of Aceh}

The per capita Gross Regional Domestic Product is the rough size of the level of welfare of a certain region at a certain time. The per capita Gross Regional Domestic Product is obtained by dividing the GRDP by the population size of a certain region.

\subsection{Analysisof the Regional Development Gap}

The gap for this region is due to the comparative differences between regions, which cause one or several areas to be more advanced than others. The following are the Williams on indices of three regions.

Table 2 Regional Development Gap of the Province of Aceh, 2000-2013

\begin{tabular}{lcccc} 
No & Year & $\begin{array}{c}\text { North-East } \\
\text { Region }\end{array}$ & $\begin{array}{c}\text { Middle- } \\
\text { Southeast } \\
\text { Region }\end{array}$ & $\begin{array}{c}\text { West-South } \\
\text { Regions }\end{array}$ \\
1. & 2000 & 0,00 & 0,03 & 0,01 \\
2. & 2001 & 0,06 & 0,04 & 0,01 \\
3. & 2002 & 0,05 & 0,03 & 0,01 \\
4. & 2003 & 0,05 & 0,03 & 0,02 \\
5. & 2004 & 0,04 & 0,06 & 0,05 \\
6. & 2005 & 0,05 & 0,04 & 0,02 \\
7. & 2006 & 0,08 & 0,02 & 0,02 \\
8. & 2007 & 0,09 & 0,02 & 0,02 \\
9. & 2008 & 0,10 & 0,03 & 0,02 \\
10. & 2009 & 0,11 & 0,03 & 0,03 \\
11. & 2010 & 0,09 & 0,02 & 0,02 \\
12. & 2011 & 0,08 & 0,02 & 0,02 \\
13. & 2012 & 0,08 & 0,02 & 0,02 \\
14. & 2013 & 0,08 & 0,02 & 0,02 \\
\hline
\end{tabular}

Source: Research Results 
Table1 shows the condition of the regional development gap in three areas of the Province of Aceh, all of which were varied. The largest gap occurred for the North-East region with a value of 0.11 in 2009 , and this occurred due to the difference between the total average per capita GRDP of all regions and the per capita GRDP of the North-East region, which was too great; the smallest gap occurred in 2000 with 0 , and this was caused by the per capita GRDP of the NorthEast region being balanced by the population. The second-largest gap was experienced by the Middle-Southeast region with a high of 0.09 in 2004, while the smallest gap was experienced by the West-South region with a high of 0.05 in 2004.

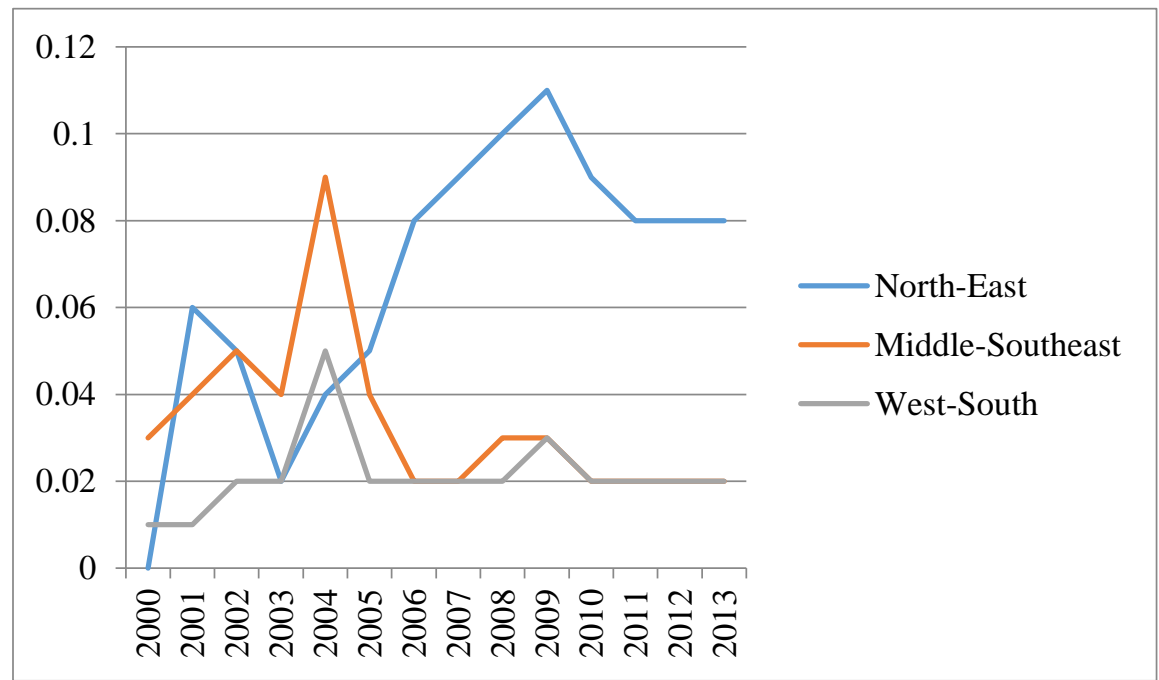

Figure 2 Regional Development Gap of the Province of Aceh, Years 2000-2013

Source: Research Results

Figure 2 shows the condition of the regional development gap in three areas of the Province of Aceh also seen in Table2, for which the largest gap was for the North-East region, followed by the Middle-Southeast region, and finally the WestSouth region as having the smallest gap.

\subsection{Discussion}

\subsubsection{Semi-Logarithm Regression}

Table 3 Semi-Logarithm Regression

\begin{tabular}{|l|c|c|c|c|}
\hline \multicolumn{1}{|c|}{ Variable } & $\begin{array}{c}\text { Co efficiency of } \\
\text { Estimation }\end{array}$ & $\begin{array}{c}\text { Sandard } \\
\text { Error }\end{array}$ & t-Ratio & Sig \\
\hline Per capita & & & & \\
Constant-Price & $-1,8942$ & 0,4202 & $-4,508$ & 0,001 \\
GRDP of North- & 0,1263 & 0,0270 & 4,671 & 0,001 \\
East Region & & & \\
\hline R =0,8032 & & \\
R Square =0,6452
\end{tabular}




\begin{tabular}{|c|c|c|c|c|}
\hline $\begin{array}{l}\text { Per capita } \\
\text { Constant-Price } \\
\text { GRDP of Middle- } \\
\text { Southeast Region }\end{array}$ & $\begin{array}{l}0,6441 \\
0,0400\end{array}$ & $\begin{array}{l}0,1935 \\
0,0126\end{array}$ & $\begin{array}{c}3,329 \\
-3,178\end{array}$ & $\begin{array}{l}0,008 \\
0,006\end{array}$ \\
\hline \multicolumn{5}{|l|}{$\begin{array}{l}\mathrm{R}=0,6760 \\
\mathrm{R} \text { Square }=0,4570\end{array}$} \\
\hline $\begin{array}{l}\text { Per } \\
\text { Constant-Price } \\
\text { GRDP of West- } \\
\text { South Regions }\end{array}$ & $\begin{array}{c}-0,4703 \\
0,0318\end{array}$ & $\begin{array}{l}0,3205 \\
0,0208\end{array}$ & $\begin{array}{c}-1,468 \\
1,532\end{array}$ & $\begin{array}{l}0,168 \\
0,151\end{array}$ \\
\hline $\begin{array}{l}\mathrm{R}=0,4045 \\
\mathrm{R} \text { Square }=0,1636\end{array}$ & & & & \\
\hline
\end{tabular}

Source: Research Results

Based on Table3, it can be seen that in the North-East, Middle-Southeast, and West-South regions, the per capita GRDP had a positive influence on the regional development gap of the Province of Aceh. The constant estimation coefficient for the North-East region had a value of -1.8942; this showed that if the per capita GRDP for the North-East region was equal to zero (0) or unchanged, then the regional development gap for the Province of Aceh would decrease by 1.8942. The constant estimation coefficient for the Middle-Southwest region had a value of 0.6441 ; this showed that if the per capita GRDP for the Middle-Southeast region was equal to zero $(0)$ or unchanged, then the regional development gap for the Province of Aceh would increase by 0.6441. The constant estimation coefficient for the West-South region had a value of -0.4703 ; this showed that if the per capita GRDP for the West-South region was equal to zero $(0)$ or unchanged, then the regional development gap for the Province of Aceh would decrease by 0.4703 .

The regression coefficient for the per capita GRDP for the North-East region had a value of 0.1263 ; this showed that if the per capita GRDP increased by 1 percent, then the regional development gap for the Province of Aceh would increase by 0.1263 percent with the assumption that other factors did not change. The Middle-Southeast region had a regression coefficient for the per capita GRDP of 0.0400; this showed that if the per capita GRDP increased by 1 percent, then the regional development gap for the Province of Aceh would increase by 0.0400 percent with the assumption that other factors did not change. The West-South region, based on the research results, had a regression coefficient for the per capita GRDP of 0.0318; with this, if the per capita GRDP increased by 1 percent, then the regional development gap for the Province of Aceh would increase by 0.0318 percent, with the assumption that other factors did not change.

\subsubsection{Correlation Analysis and Determination}

Based on the research that was conducted, it can be explained that the coefficient for the independent variable (per capita GRDP) for the North-East region was $R=0.8032$, which positively explained that there was a relationship between the per capita GRDP and the regional development gap of the Province of Aceh by a factor of 0.8032 . The Middle-Southeast region had a value of $R=0.6760$, which positively explained that there was a relationship between the per capita GRDP and the regional development gap of the Province of Aceh by a factor of 
0.6760. The West-South region had a value of $\mathrm{R}=0.4045$, which positively explained that there was a relationship between the per capita GRDP and the regional development gap of the Province of Aceh by a factor of 0.4045 .

The coefficient of determination value ( $\mathrm{R}$ Squared) for the North-East region was $\mathrm{R}^{2}=0.6452$, which meant that the regional development gap for the Province of Aceh was affected by 64.52 percent by the per capita GRDP, while the remaining 35.48 percent was the effect of other variables outside of this research. The Middle-Southeast region had a coefficient of determination value of $\mathrm{R}^{2}=$ 0.4570, which meant that the regional development gap for the Province of Aceh was affected by 45.70 percent by the per capita GRDP, while the remaining 54.30 percent was the effect of other variables outside of this research. Meanwhile, the coefficient of determination value for the West-South region was $\mathrm{R}^{2}=$ 0.1636, which meant that the regional development gap for the Province of Aceh was affected by 16.36 percent by the per capita GRDP, while the remaining 83.64 percent was the effect of other variables outside of this research.

\subsection{3 t-Test}

Based on the research results for the per capita GRDP variable for the North-East region, it was found that $t_{\text {count }}>t_{\text {table, }}$ as $4.671>1.7823$; with $\alpha=0.05$, the degree of significance was less than 0.05 as $0.001<0.05$ and thus $\mathrm{H}_{0}$ was rejected and $\mathrm{H}_{1}$ was accepted, meaning that the per capita GRDP variable individually had a significant effect on the regional development gap of the Province of Aceh. For the Middle-Southeast region, the per capita GRDP variable was found to have $\mathrm{t}_{\text {count }}<\mathrm{t}_{\text {tableas }}-3.178<1.7823$; with $\alpha=0.05, \mathrm{H}_{0}$ was accepted and $\mathrm{H}_{1}$ was rejected, meaning that the per capita GRDP variable individually had no significant effect on the regional development gap of the Province of Aceh. For the West-South region, the per capita GRDP variable was found to have $t_{\text {count }}<t_{\text {tableas }} 1.532<$ 1.7823 ; with $\alpha=0.05, \mathrm{H}_{0}$ was accepted and $\mathrm{H}_{1}$ was rejected, meaning that the per capita GRDP variable individually had no significant effect on the regional development gap of the Province of Aceh.

Further, the results of regression in this research resulted in regression coefficients that stated that for the North-East, Middle-Southeast, and West-South regions, there was a positive relationship between the per capita GRDP variable and the regional development gap variable.

\section{CONCLUSION}

\subsection{Conclusion}

a. The regional development gap of three regions in the Province of Aceh measured by the Williamson Indices for the research time period of years 2000-2013 showed that the largest gap was experienced by the North-East region, followed by the Middle-Southeast and West-South regions.

b. Based on the results of the regression coefficients for the North-East, MiddleSoutheast, and West-South regions, there was a positive relationship between the per capita GRDP variable and the regional development gap variable.

\subsection{Suggestions}

a. The Province of Aceh should conduct efforts to reduce the regional development gap caused by the uneven per capita income, in particular efforts to even out the per capita income and employment. 
b. There should be a hands-on people empowerment program from the government so that the people can independently pursue opportunities.

\section{References}

Amalia, L. (2007) Economic Development, First Edition. Yokyakarta: Graha Science.

Adisasmita, R. (2005). Fundamentals of Regional Economics. Yogyakarta: Graha Science.

BPS. Aceh in Figures. (2015). Central Bureau of Statistics Province. Banda Aceh.

BPS. Aceh in Figures. Central Bureau of Statistics Province. Banda Aceh. 20002014

Hasan, I. (2001). Principles of Materials Research Methodology and Applications. PT Ghalia Indonesia. Bogor.

Husaini, U. et.all. (2006). Introduction to Statistics. Earth Asara. Jakarta.

Jhingan M.L. (2007). Economic Development and Planning. Jakarta: PT. King Grafindo.

Tadaro. (2006). Economic Development, Ninth Edition. Jakarta: Erlangga.

Sarwoko. (2005). Basics of Econometrics. Yogyakarta: Andi.

Sukirno, S. (2004). Macro Economic Theory and Introductions, Third Edition. Jakarta: PT Raja Grafindo.

Suprato, J. (2004). Statistics, Sixth Edition. Jakarta: Erlangga. Jakarta.

Sjafrizal. (2008). Regional Economic. Padang: Badouse Media.

Tarigan, R. (2005). Regional Economic: Theory and Applications, Revised Edition. Jakarta: PT Bumi Script.

Tadaro, M. P., \& Smith, S. C. (2006). Economic Development, Ninth Edition. Jakarta: Erlangga. 